\title{
Exploration of Graffiti Art in Children's Art Teaching Reform
}

\author{
$\mathrm{Xu} \mathrm{Li}$ \\ Department of Fine ArtsChongqing University of Education \\ Chongqing, 400067, China \\ 470428878@qq.com
}

\begin{abstract}
Keywords: Graffiti; Children's education; Teaching; Reform
\end{abstract}
\begin{abstract}
Children's graffiti is characterized by spontaneity, creativity and imagination. In art teaching, children have the advantages like divergent thinking and rich imagination. Graffiti art could give full play to their subjective initiative and cultivate good hobbies. Therefore, in the children's art teaching reform, it should change the original stylized teaching concept. The introduction of graffiti art in children's art teaching is to encourage the development of creativity, imagination, which could be helpful to the development of children, and also could make further exploration in the process of reform and innovation.

"Graffiti" is translated from "graffiti". It is basically interpreted as "humorous or rough words and pictures on the wall of a building or train". As a popular art form in Western graffiti, first appeared in the Tang Dynasty poet Lu Tong's poem Shi Tian Ding: "Suddenly Turn Out the Ink, Painting Like a Duck". The art of graffiti is originated in Bronx, New York.
\end{abstract}

\section{Benefits of Graffiti to Children}

Graffiti is not exclusive to adult painting. In a child's world, graffiti is an abstract abstraction of what is outside. Children have a certain knowledge of things before the graffiti, which exists in strong interest of children in things. The most basic cognitive for children on things is preference and not. The more interest in certain things, the more interest for children in paintings, higher painting quality spirits. Children's graffiti painting could also be understood from two aspects: one is the children's imagination free without the adult consciousness in the art concept completely, which could promote the development of children on the active development of uncertainty thinking for things outside; the other one is under the guidance of teachers, there is a certain aesthetic awareness of children's graffiti painting, which could subtly instill a professional concept of children, thus conducive to the improvement of children's aesthetic awareness.

Most of the adult graffiti paintings have its meaning, or concrete representation. Mature ideas, skilled use of various painting skills would have a certain control over the entire picture. Children's graffiti painting could show children's thinking and behavior in the way of painting, which not so mature thinking comparing to adult graffiti painting. However, they have unlimited imagination and creativity. At this point, adults are very restricted, because adults have a concrete understanding of what is real. This shows that children's graffiti painting shows a certain creativity. On this basis, teachers give guidance and help on children's graffiti images with adult graffiti painting expressive and figurative thinking of things to guide them to form images with language that they could understand. Such children graffiti painting works would be more expressive and appealing.

\section{Characteristics of Children's Graffiti Art}

Chen Aimin of Nanjing Xiaozhuang University, has proposed: "graffiti is a work that should be completed by hands and brain and use, which objectively enhances the coordination and control ability of hands and brain, inspires the imagination and creativity of children". Brain, eyes, hands are used at the same time in children's graffiti painting; the active brain promotes active and quick thinking; eyes are the window of the heart, which opens up the horizons and improve the appreciation ability; The use of the hand could not only exercise the strength of the arm, but also 
make the fingers more flexible; There is a close connection between these three. Not only that, but this kind of graffiti behavior also has practical and effective value for the later period, whether it is study or painting.

A form of children's naivete is graffiti, which displays not only in the selection of carriers; whether the wall, or paper, they are good "creation" carrier, and could be shown in the creation of arbitrary, so random graffiti is actually called children graffiti. When children doodle, the limited knowledge reserve makes the expression ability slightly insufficient without concrete image, but the emotion expressed through the picture is undeniable with intense appeal. The emotion that supports this kind of emotion is the innate aesthetic ability of a child. It may be emotional or rational, but the examination of beauty also has its own judicial ability. Children's graffiti art is closely related to children's development.

It is not difficult to find that children's graffiti painting possess spontaneous and random and creative features that adults rarely possess, which are worth encouraging and development. As these kind of development is not bound by concrete thinking, it active exercise children's thinking acumen and thought.

\section{Some of the Drawbacks of Today's Graffiti Art in Children's Education}

In this age of rapid growth, competition has become more than just between adults. Parents' idea of "wishing their children had a bright future" brings undue pressure on young children. Most parents think that they should develop all kinds of special skills to give children a better competitive advantage from childhood. Of course, painting is also the most common specialty. What kind of art training institutions could really improve children's painting ability and appreciation? According to the survey, a large number of training institutions are commercial. Therefore, with profit as the main purpose, there is no systematic teaching plan and in-depth discussion of the teaching and research team in the painting teaching. Then, what are the disadvantages of these training institutions?

Lack of Targeted Classification Teaching. In the content of teaching, there is no corresponding teaching according to the age of children, but also failed to teach students in accordance with their aptitude. The training organizations only gathers children of different ages together, and taught graffiti paintings that adults thought they should learn. In this way, this teaching would make young children unable to learn knowledge, while older children have no strong interest in too simple subjects. Sometimes parents add fuel to the flames, some even spoil things by excessive enthusiasm thinking, and put figurative thinking on children. The name of more realistic, the better limits children's spontaneity and creativity.

Stylized Teaching Methods. Take the painting of concrete things as the evaluation index of the painting level, the standard of the works is the degree of similarity make thinking mode of children has been imprisoned and solidified. Usually, teachers adopt a fixed teaching template in children's art teaching classroom. As a result, it is not difficult to imagine that the graffiti works for a class of children is similar under stereotyped teaching materials and the same teaching materials. This rigid and stylized children's art teaching greatly reduces the active degree of children's thinking, and is a problem that needs to be improved urgently.

Lack of Communication in Classroom Teaching. Children are rich in inner activities, curious about things in the outside world, and like to express their inner activities in the form of paintings. However, under the incorrect guidance, graffiti talent not only could not get play, but also would be bound by adult teaching mode, The wonderful imagination world is located in concrete thinking. Children's imagination and creativity are infinite. Limiting children's development space is equal to killing they nature.

\section{Suggestions for Optimizing Graffiti Art in Children's Education}

Encourage divergent thinking and affirm self-expression. In the process of painting, children's thinking is dominant, the role of teachers is to guide, inspire and encourage. When the children do not to imagine, even after the guide and inspire by teachers, they still have a positive sense of 
self-affirmation; at this time, the teacher do not encourage, which would produce negative factors to bother children in the future such as let the self-affirmation maybe in the future, it would cause no confidence and other negative factors of distress, so encouraging children self-expression is an essential link.

Pay Attention to Children's Emotional Catharsis in Graffiti Art. Children's graffiti is largely a depiction of object in the reality and break the space constraints in the reality, which gives full play to the initiative, has the artistic appeal communicated with the art master. Mondrian's Grey Tree is a good showing reality geometry and abstraction of art masters, which also inject their own poetic feeling. Children also have the same ideological consciousness. As there are no figurative consciousness for the external reality of things, painting expression is full of their own emotional expression for things graffiti. Therefore, whether the artist or children, this simple and abstract art graffiti in common lies on the feelings of anger and the cry of inner world without losing the true innocence; this picture is more concise, expressive and creative.

Let Children Have Fun in Graffiti Art. Graffiti painting is fun and interesting for children. Children's mind is pure, which occupies the mind advantage while painting; not only that, for cognition, unlike adults of cognition of things between reality and imagination, the children have boundless imagination cognition, even exaggeratedly. In graffiti teaching, children's graffiti that allows children to play their own creativity, which represents the tension and independent innovation.

Building a Display Platform is also a Way for Children to Develop Graffiti. For children, a sense of achievement is a great boost to self-confidence. For a good child graffiti work, parents or teachers should give timely encouragement, correct guidance to let it continue to develop. In the rapid development of modern information network technology, various forms of public platform could meet the demand of works exhibition, which could enhance the confidence of the children. It is very beneficial for the development of children's physical and mental health.

\section{Prospect of Graffiti Art for Children's Education}

Pay attention to the development of children's graffiti art with a positive attitude as children are the freshest blood of society, represent the vigor and vitality as well as the future. In the way of education, I hope to pay more attention to children's art education, graffiti art thinking inspiration, encourage and guide children's development. In the content of education, we hope that we could have teaching courses corresponding to children's corresponding cognitive stage, and we could adopt appropriate ways of correspondence teaching, which would make children more receptive and more emotionally interested. In the form of teaching, we hope to be innovative, and consider the teaching methods from the children's thinking mode.

\section{References}

[1] D.M. Zeng and W. Xiong. The development and education of children's graffiti [J]. Today's education: contemporary preschool education. 2007.

[2] (USA) Lowenfeld, "creation and the growth of mind" [M], Hunan fine arts press, 1993 edition, page 87-92.

[3] L.Q. Yan, the image of children during the period of "art form." [J].experience "creative teaching, basic education forum, 2014.

[4] X.Y. Guo, W.S. Li and B.Q. Gao, children's creative study art education [J]."Silk Road", 2017 (9).

[5] L.M. Hou, When the children's early paintings Limin, and its influence on education [J]. preschool education research, $2006(01)$

[6] A.H. Song, art education research [J], creative painting and development of children's creativity, 2012 (2), 114-115. 